\title{
ADDENDA AND ERRATA
}

Acta Cryst. (1995). C51, 340

\section{Comments on wadalite, $\mathrm{Ca}_{6} \mathrm{Al}_{5} \mathrm{SiO}_{16} \mathrm{Cl}_{3}$, and the structures of garnet, mayenite and calcium chlorosilicate. Addendum. By F. P. GLASSER, Department of Chemistry, University of Aberdeen, Meston Walk, Old Aberdeen AB9 2UE, Scotland}

(Received 7 August 1994; accepted 6 December 1994)

\begin{abstract}
Tsukimura, Kanazawa, Aoki \& Bunno [Acta Cryst. (1993), C49, 205-207] have reported the structure of a new mineral, wadalite. They compared the structure with that of grossular garnet. The purpose of this note is to point out that wadalite is isostructural with a previously reported synthetic chlorosilicate phase [Feng, Glasser, Howie \& Lachowski (1988). Acta Cryst. C44, 589-592].

Tsukimura, Kanazawa, Aoki \& Bunno (1993) reported the structure of a new mineral, wadalite, and assigned it the formula $\mathrm{Ca}_{6} \mathrm{Al}_{5} \mathrm{SiO}_{16} \mathrm{Cl}_{3}$. Its structure is described as a derivative of that of grossular garnet, $\mathrm{Ca}_{6} \mathrm{Al}_{4}\left(\mathrm{SiO}_{4}\right)_{6}$ (Abrahams \& Geller, 1958), but with unoccupied tetrahedral sites and lowered symmetry: $I a 3 d$ in grossularite but $I \overline{4} 3 d$ in wadalite.

The purpose of this note is to point out that wadalite is isostructural with a synthetic chlorosilicate phase, the structure of which was reported by Feng, Glasser, Howie $\&$ Lachowski (1988). Both have space group $I \overline{4} 3 d$ with $a$ $=11.981$ (6) $\AA$ for the chlorosilicate and $a=12.001$ (2) $\AA$ for wadalite. The chemical formulae are nearly identical: per 12 $\mathrm{Ca}$ atoms, the chlorosilicate has $5.4 \mathrm{Cl}$ atoms, compared to $\sim 5.2 \mathrm{Cl}$ atoms in wadalite. Other unit-cell contents and atomic positions are essentially identical. Tsukimura et al. (1993) were apparently unaware of the isostructural relationship between $\mathrm{Ca}_{12} \mathrm{Al}_{10.6} \mathrm{Si}_{3.4} \mathrm{O}_{32} \mathrm{Cl}_{5.4}$ and wadalite.
\end{abstract}

The published description of the wadalite structure concentrates on its similarity to grossularite. While the similarity is not in dispute, the much closer relationship of wadalite to the mayeriite family of minerals should not be overlooked. Williams (1973) reported the structure of synthetic $\mathrm{Ca}_{12} \mathrm{Al}_{14} \mathrm{O}_{33}$. The presence of a poorly bonded $\mathrm{O}$ atom facilitates its replacement by $2\left(\mathrm{~F}^{-}, \mathrm{Cl}^{-}, \mathrm{OH}\right)$, yielding phases of the type $\mathrm{Ca}_{12} \mathrm{Al}_{14} \mathrm{O}_{32}\left[\mathrm{O},(\mathrm{OH})_{2}, \mathrm{~F}_{2}, \mathrm{Cl}_{2}\right]$. Naturally occurring meyenite is close to $\mathrm{Ca}_{12} \mathrm{Al}_{14} \mathrm{O}_{32}(\mathrm{OH})_{2}$ in composition; the synthetic chlorosilicate phase, as well as wadalite, derive from this chemistry by incorporating excess $\mathrm{Cl}^{-}$with substitution of $\mathrm{Si}^{4+}$ for $\mathrm{Al}^{3+}$ for charge compensation. The structure and nature of stable crystallochemical substitutions thus differ significantly from those typical of garnets and the more appropriate classification of wadalite as a member of the mayenite-type family better accounts for some of the unusual physical and electrical properties of this group (see, for example, Lacerda, Irvine, Glasser \& West, 1988).

\section{References}

Abrahams, S. C. \& Geller, S. (1958). Acla Cryst. 11, 437-441

FenG, Q. L., Glasser, F. P., HowIE, R. A. \& LaChOWsKi, E. (1988). Acta Cryst. C44, 589-592.

Lacerda, M., Irvine, J. T. S., Glasser, F. P. \& West, A. R. (1988). Nature (London), 232, 525-526.

Tsukimura, K., Kanazawa, Y., Mashahiro, A. \& Bunno, M. (1993). Acta Cryst. C49, 205-207.

Williams, P. (1973). Acta Cryst. B29, 1550-1551.

Acta Cryst. (1995). C51, 340

Functionalized hydrocarbons with condensed ring skeletons. XV. A (methoxymethoxymethyl)tricyclo[9.4.0.0 ${ }^{2,8}$ pentadec-9-ene. Erratum. By ANDRE G. MICHEL, Laboratoire de Chimie Structurale et Modélisation Moléculaire, Département de chimie, Faculté des Sciences, Université de Sherbrooke, Sherbrooke, Québec, Canada $J 1 K 2 R 1$, DenNIS G. HALL, Laboratoire de Synthèse Organique, Département de chimie, Faculté des Sciences, Université de Sherbrooke, Sherbrooke, Québec, Canada $J 1 K 2 R 1$, and MARC DROUIN, Laboratoire de Chimie Structurale et Modélisation Moléculaire, Département de chimie, Faculté des Sciences, Université de Sherbrooke, Sherbrooke, Québec, Canada J1K $2 R 1$

(Received 1 October 1994)

\section{Abstract}

In the paper by Michel \& Drouin [Acta Cryst. (1993), C49, 1830-1833], the authors are given incorrectly. The authors should be André G. Michel, Dennis G. Hall \& Marc Drouin, with addresses as shown above.

All relevant information is given in the Abstract. 